\title{
Performance of an Environmentally Friendly Alternative Fluid in a Loop Heat Pipe-Based Battery Thermal Management System
}

\author{
Marco Bernagozzi $^{1, * \mathbb{D}}$, Nicolas Miché ${ }^{1} \mathbb{D}$, Anastasios Georgoulas ${ }^{1} \mathbb{D}$, Cedric Rouaud $^{2}$ and $^{\text {Marco Marengo }}{ }^{1} \mathbb{D}$ \\ 1 Advanced Engineering Centre, University of Brighton, Brighton BN2 4GJ, UK; \\ N.D.D.Miche@brighton.ac.uk (N.M.); A.Georgoulas@brighton.ac.uk (A.G.); \\ M.Marengo@brighton.ac.uk (M.M.) \\ 2 Ricardo Plc, Shoreham-by-Sea BN43 5FG, UK; Cedric.Rouaud@ricardo.com \\ * Correspondence: m.bernagozzi2@brighton.ac.uk
}

check for updates

Citation: Bernagozzi, M.; Miché, N.; Georgoulas, A.; Rouaud, C.; Marengo, M. Performance of an

Environmentally Friendly Alternative Fluid in a Loop Heat Pipe-Based Battery Thermal Management System. Energies 2021, 14, 7738. https:// doi.org/10.3390/en14227738

Academic Editor:

Christopher Micallef

Received: 30 October 2021

Accepted: 16 November 2021

Published: 18 November 2021

Publisher's Note: MDPI stays neutral with regard to jurisdictional claims in published maps and institutional affiliations.

Copyright: (c) 2021 by the authors. Licensee MDPI, Basel, Switzerland. This article is an open access article distributed under the terms and conditions of the Creative Commons Attribution (CC BY) license (https:/ / creativecommons.org/licenses/by/ $4.0 /)$.

\begin{abstract}
The present investigation aims to devise a thermal management system (TMS) for electric vehicles able to improve on limitations like charging time and all-electric range, together with the safety and environmental impact of the chosen thermal medium. A research gap is identified, as focus is often on addressing system thermal performance without considering that the thermal medium must not only provide suitable performances, but also must not add risks to both passengers and the environment. Thus, this work proposes an innovative cooling system including graphite sheets and a Loop Heat Pipe, filled with Novec ${ }^{\mathrm{TM}} 649$ as working fluid, due to its exceptional environmental properties $(\mathrm{GWP}=1-\mathrm{ODP}=0)$ and safety features (non-flammable, non-toxic, dielectric). A three-cell module experimental demonstrator was built to compare temperatures when the proposed TMS is run with Novec ${ }^{\mathrm{TM}} 649$ and ethanol. Results of testing over a bespoke fast charge driving cycle show that Novec $^{\mathrm{TM}} 649$ gave a faster start-up and a slightly higher maximum temperature $\left(0.7^{\circ} \mathrm{C}\right)$, meaning that the gains in safety and lower environmental impact brought by Novec ${ }^{\mathrm{TM}} 649$ came $^{\circ}$ without lowering the thermal performance. Finally, the TMS was tested under three different fast charge conditions $(1 \mathrm{C}, 2 \mathrm{C}, 3 \mathrm{C})$, obtaining maximum temperatures of $28.4{ }^{\circ} \mathrm{C}, 36.3^{\circ} \mathrm{C}$ and $46.4{ }^{\circ} \mathrm{C}$, respectively.
\end{abstract}

Keywords: electric vehicles; batteries; thermal management; loop heat pipe; low pollutant fluid; experimental characterisation

\section{Introduction}

The evident deteriorating of planetary conditions during the last 40 years has pushed governments worldwide to take actions to reduce the emissions of greenhouse gases (GHG). These long-life gases trap radiating heat that would otherwise be released to outer space, and eventually emit this heat back to the atmosphere in the so-called "greenhouse effect". Amongst the sources of these harmful emissions, the transportation sector is a major contributor, accounting for $28 \%$ of the 2018 overall $\mathrm{UK} \mathrm{CO}_{2}$ emissions (this being the predominant cause of the GHGs) [1], and for the $34 \%$ of all $\mathrm{CO}_{2}$ emissions in the US [2]. This is part of the reason why the electrification of the transportation sector is considered one of the solutions to tackling the climate emergency. The most suitable energy storage method for this application, for now, is Li-ion batteries.

Electric vehicle (EV) sales had increased with respect to the previous year by $40 \%$ in 2019 [3], and by 43\% in 2020 [4], despite the Covid-19 pandemic. However, ownership cost, limited all-electric driving range and long recharging times remain the main areas [5] where improvements must be made in order to further increase the worldwide dissemination of electric cars, which are still stuck at $1 \%$ of the global stock of vehicles. These three factors are all linked to the thermal management of the energy storage unit of the vehicle, 
namely the battery pack. In fact, temperature has been proven to greatly influence the behaviour of Li-ion cells, from power output to operative life. Research has shown that, considering extremely severe low temperature test conditions such as $-40{ }^{\circ} \mathrm{C}$, an 18650 type Li-ion battery can only deliver $5 \%$ and $1.25 \%$ of the initial energy capacity and power capacity, respectively [6]. At higher temperatures, the same type of cell shows capacity loss of $36 \%$ after being cycled 800 times at $45{ }^{\circ} \mathrm{C}$ and lost more than $70 \%$ at $55{ }^{\circ} \mathrm{C}$ after 490 cycles [7]. Furthermore, another crucial consideration regarding temperature control for Li-ion batteries is safety: in fact, a potentially disruptive condition called thermal runaway begins around $130{ }^{\circ} \mathrm{C}$, where the separator melts and a strongly exothermic reaction takes place leading to smoke, fire and explosions [8].

Therefore, a properly designed thermal management system (TMS) dedicated to an EV battery pack needs to be able to contain cell temperature in an interval identified as 25-40 ${ }^{\circ} \mathrm{C}$ [9] for optimal performance and operative life, or below $50{ }^{\circ} \mathrm{C}$ for still acceptable performance [10], while not exceeding $60^{\circ} \mathrm{C}$ under normal operating condition for safety reasons [11]. Moreover, the temperature difference between the cells inside a single module should not exceed $5{ }^{\circ} \mathrm{C}$, and across a single cell should be between $3-5{ }^{\circ} \mathrm{C}$ [12]. Until now, EV manufacturers have relied on two methods of thermal management, air [13] and liquid convection [12], to manage the abovementioned requirements, both having their pros and cons. Typically, air convection is regarded as the simplest, lightest and cheapest of the two methods, whereas for liquid, TMS costs and complexity increase with the number of parts. However, air convection cannot cope with the high thermal loads that are usually connected with the high C-Rates typical of fast charging. Moreover, due to the inadequate thermal properties of the thermal medium (air), this method cannot maintain a homogeneous temperature distribution along the battery module. On the other hand, a liquid TMS, usually in the form of tubing or cold plates, is more efficient in containing the temperature increase during fast charging than the air counterpart. Liquid TMS generally result in a lower parasitic power consumption than air TMS, due to the presence of the fans in the latter. Extensively researched but not yet employed is the use of other TMS technologies such as phase change materials (PCM) [14], heat pipes [15] and boiling [16] (also referred to as immersion cooling). PCM based TMS have the benefit of passively cooling or heating the battery module and absorbing or releasing latent heat, respectively. However, they have low thermal conductivity and they tend to increase weight, encumbrance and cost of the design. Heat pipes and boiling, despite being very promising for their exceptional heat transfer capabilities, still present design challenges in terms of selecting the best cooling solutions for the condenser, minimizing weight and optimizing interfacing with the modules.

In a previous work by the Authors [17], a comparison between these technologies was carried out over parameters such as power consumption, weight and encumbrance (both influencing the energy density), cost, maintenance, complexity (number of parts) and cooling performance. The ranking was assigned on a low, medium and high basis and is reported in Table 1. Thanks to Table 1, the heat pipe technology was chosen and, in particular, the Loop Heat Pipe (LHP), which was preferred to standard sintered HP for their ability to transport heat along long lengths. In that work, it was demonstrated that not only can LHP successfully contain the cell maximum temperature during fast charging, but also it can outperform a standard liquid cold plate TMS by giving a $3.6^{\circ} \mathrm{C}$ lower maximum temperature [17]. The proposed TMS was able to respect both cell and module temperature requirements as well.

Temperature requirements are not the only requirements for EV TMS. In fact, safety, environmental impact and temperature range are three crucial aspects original equipment manufacturers (OEMs) are pressured to consider when selecting the working fluid for a battery TMS. Given the recent surge in interest on the TMS for EV, research is focused on achieving the best possible performances perhaps disregarding other important limitations posed by the automotive industry, especially with regard to safety (intended as added risk in case of failure) and environmental impact. One important factor often overlooked is 
the flammability of the thermal medium, as, for instance, most research on PCM cooling for batteries employs paraffin wax, which is a flammable material [14]. Moreover, in HP, most common working fluids are flammable, such as ethanol, acetone, ethyl alcohol, or electrical conductors, such as water [17]. Similarly, liquid-based TMS used a various range of working fluids, such as water [18,19], an ethylene glycol-water mixture [20,21], and refrigerants (R134a) [22,23], which have issues in of being electrical conductors, flammable, and have very high GWPs (1300), respectively.

Table 1. Comparison of TMS solutions for EVs, over key parameters linked to the issues raised by the costumers in purchasing an EV [17].

\begin{tabular}{cccccc}
\hline Parameter & Air & Liquid & PCM & Boiling & Heat Pipes \\
\hline Power Consumption & High & Medium & Low & Low & Low \\
Weight & Low & High & High & Medium & Medium \\
Encumbrance & Medium & Medium & High & Medium & Medium \\
Cost & Low & High & High & High & Medium \\
Maintenance & Medium & Medium & Low & Low & Low \\
Complexity/\#parts & Low & High & Low & High & Medium \\
Cooling Performance & Low & High & Low & High & High \\
\hline
\end{tabular}

From this analysis of the current research on EV TMS, what emerges is a lack of an efficient cooling method for TMS that considers not only the thermal performance but also the safety and environmental impact of the cooling medium. With this in mind, in this work, a thermal management system with LHPs and graphite sheets is proposed together with the use of a novel synthetic fluid Novec ${ }^{\mathrm{TM}} 649$, developed by $3 \mathrm{M}^{\mathrm{TM}}$. This design allows for excellent cooling performance with no parasitic power consumption (due the passive nature of the LHP), thereby ideally increasing the all-electric range of the vehicle and allowing for shorter fast charge times. The chosen fluid possesses the desired physical properties, in conjunction with favorable features such as non-flammability, a low freezing point and a GWP of 1 , hence standing out from the other working fluids used in both passive and active TMS for EV.

LHPs were only employed twice before in a battery thermal management system, firstly in a work by Putra et al. where they applied the device to a single cell [24], then by the current authors [17], with regard to the application of LHPs to a battery module. This would make the present work the third experimental work on the application of LHPs to battery thermal management systems. It is the first time a novel environmentally-friendly fluid is used as a working fluid of an LHP, but likely it is also the first time that a fluid with these properties (non-flammable and non-toxic, ultra-low GWP, inert, low freezing point) is used as working fluid for a heat pipe in general.

The aim of this investigation was to experimentally assess the performance of the Novec $^{\mathrm{TM}} 649$ fluid in the proposed TMS by comparing them against the performance of an already well-established working fluid in the sector of passive two-phase devices such as ethanol. After this, the performances of the proposed TMS are evaluated over a series of fast charge cycles in order to address its applicability to the EV market. The present paper will describe first the proposed design in Section 2; in Section 3, the experimental set-up is explained together with the motivations behind the choice of Novec ${ }^{\mathrm{TM}} 649$ working fluid. Section 4 presents the experimental results of the comparison with ethanol and the performance during fast charge tests at $1 \mathrm{C}, 2 \mathrm{C}$ and $3 \mathrm{C}$.

\section{Loop Heat Pipe Thermal Management Design}

A LHP, as shown in Figure 1, is a two-phase passive thermal device, evacuated and partially filled with a working fluid whose motion is ensured by capillarity due to the positive pressure gradient arising in the evaporator section. 


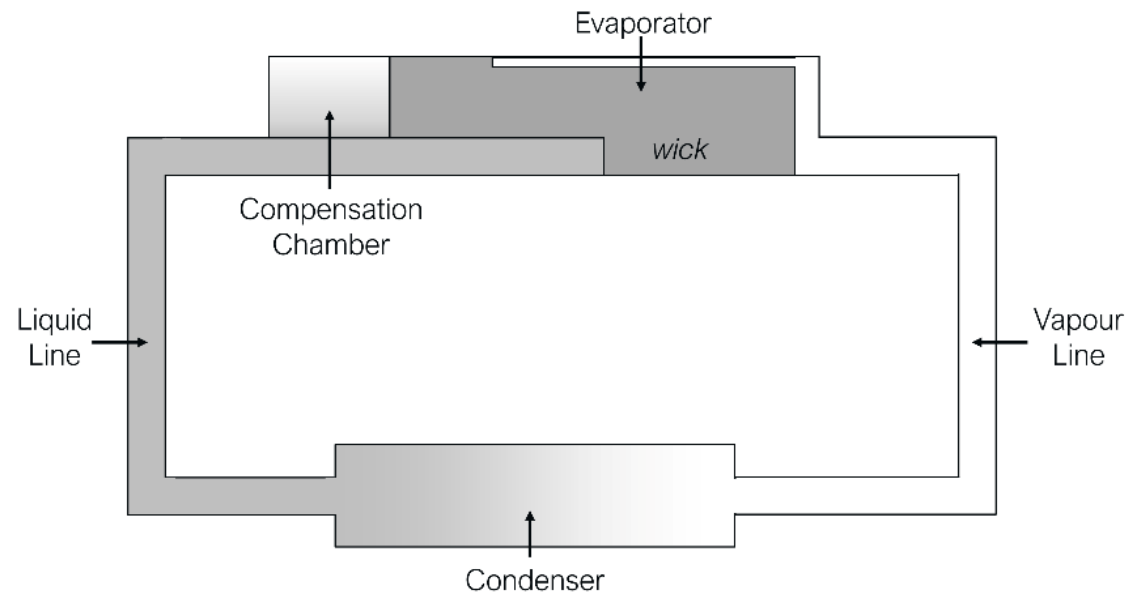

Figure 1. Loop Heat Pipe with flat plate evaporator schematic.

The evaporator consists of the compensation chamber and the wick: the compensation chamber is a two-phase reservoir that feeds the system with liquid to delay dry-out and sets the working pressure of the device. The wick is a porous structure responsible for the fluid motion, as the pores are small enough so that the fluid entrapped inside them is in a capillary state, hence it provides a positive pressure gradient following the Laplace-Young equation [25] $\Delta P_{\operatorname{cap}}=2 \sigma \cos \theta / \bar{r}$, where $\sigma$ is the surface tension of the fluid, $\cos \theta$ is $\operatorname{cosine}$ of the contact angle of the meniscus, accounting for the effect of the wettability of the wick and $\bar{r}$ is the pore size medium radius. If the pressure difference remains greater than the sum of all the load losses in the rest of the loop, the fluid evaporating from the wick will circulate in one direction only, without the need of a mechanical pump. It is this last feature that makes LHPs interesting, as they can transfer fluid (and hence heat) for long distances without the need of additional energy or moving parts. This passive operation directly contributes to the reduction of the parasitic power consumption of the EV TMS, thus contributing to the increase of the range of the vehicle and tackling one of the main customer issues against the purchase of an EV.

The proposed TMS design foresees placing a LHP at the bottom of the battery module (as presented in Figure 2), where the cells are sandwiched between graphite sheets, allowing for an increment of heat transfer in the $x-y$ plane, while at the same time hindering the heat transfer in the $\mathrm{z}$ direction. This is because of graphite sheets' typical woven structures, giving high thermal conductivity values on the parallel direction but minimal thermal conductivity in the normal direction (typically two orders of magnitude lower).

The LHP will act as thermal vector between the battery module and a remote chiller connected to the HVAC system already present in the vehicle. The feasibility of this design has been proven by an in-house experimentally validated Lumped Parameter Model in [17], but in this work only the results from the experimental demonstrator will be presented. 


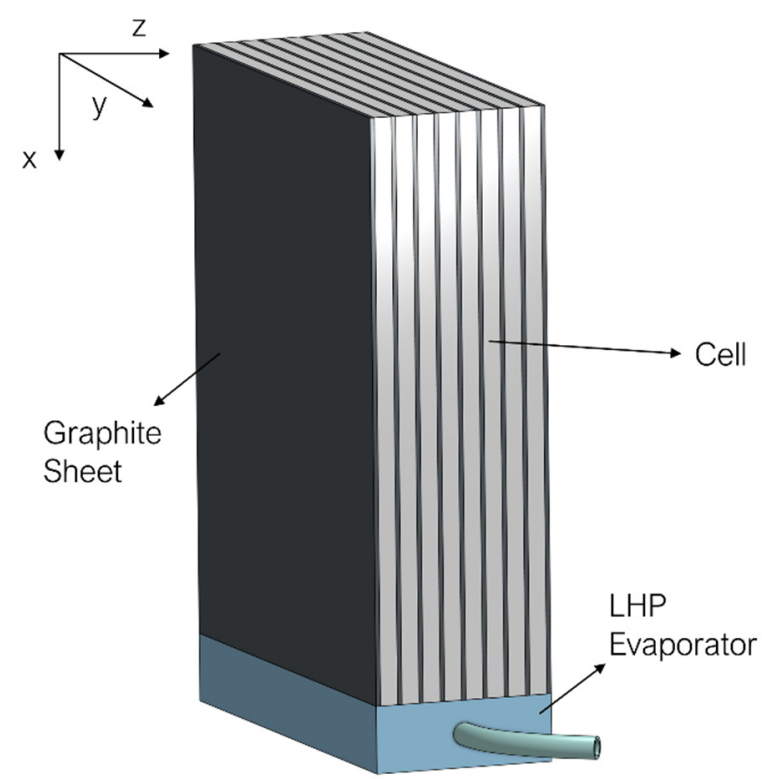

Figure 2. Loop Heat Pipe and Graphite based Thermal Management System.

\section{Experimental Set-Up}

In the schematic of the experimental set up, shown in Figure 3, the battery module is composed of three dummy cells, made from 5083-O aluminium plates having the same dimension of the considered cell type (presented in Table 2). The use of dummy cells is a proven practice already used in literature [26-28] that eliminates the risks associated with thermically stressing a real battery cell, while still allowing the evaluation of the efficiency of the cooling methods. The dimensions and physical properties of the dummy cells and graphite sheets (RS PRO) are reported in Table 2.

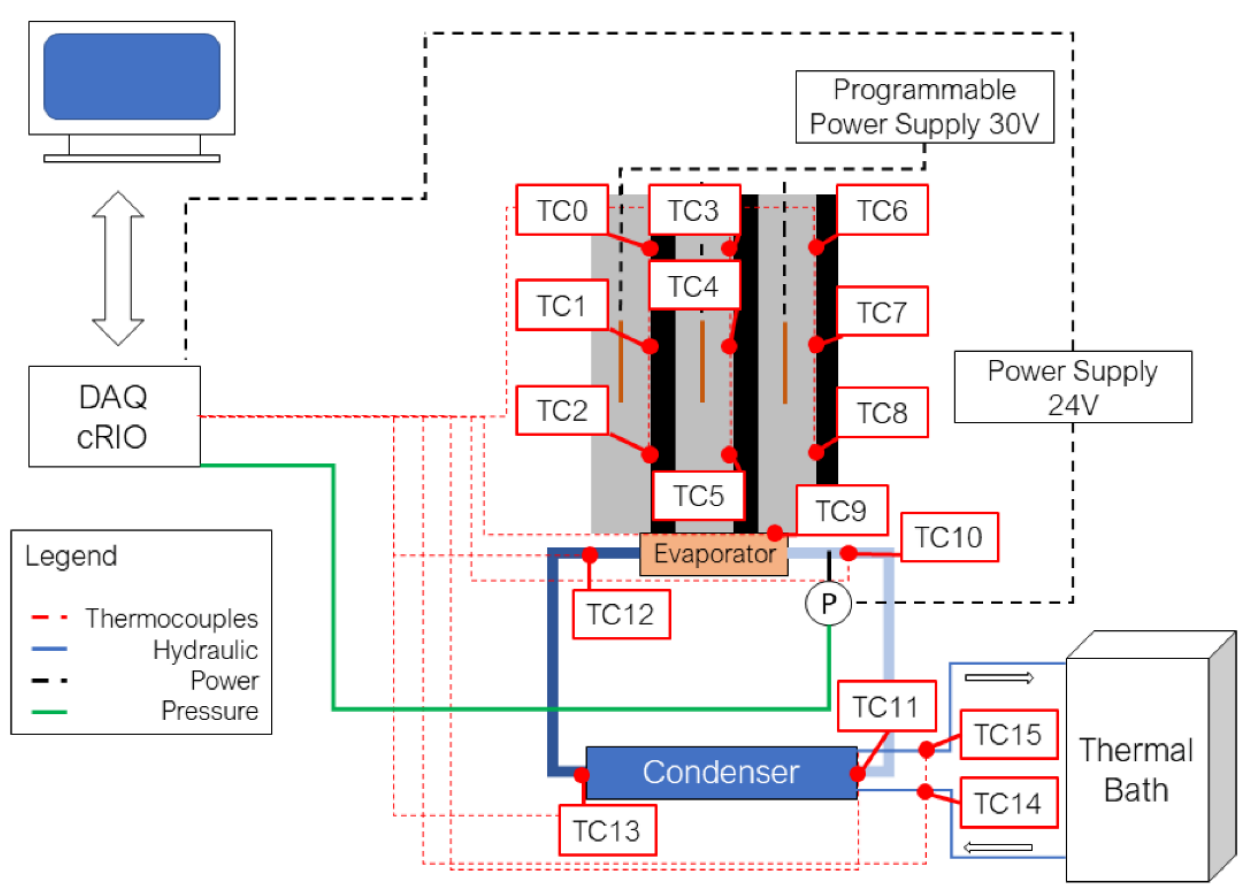

Figure 3. Block diagram of the experimental set up with details of thermocouples positioning and numbering, as well as instrumentation utilized. The thermocouples TC0 to TC 8 measure the temperature on the cell surface in contact with the graphite sheet. 
Table 2. Cells and graphite geometrical specifications and physical properties used in the LPM models.

\begin{tabular}{cccc}
\hline Parameter & Cell & Graphite & Units \\
\hline Thickness & 10 & 0.8 & $\mathrm{~mm}$ \\
Height & 96 & 96 & $\mathrm{~mm}$ \\
Width & 280 & 240 & $\mathrm{~mm}$ \\
Thermal Conductivity planar & 46 & 350 & $\mathrm{~W} / \mathrm{m} \cdot \mathrm{K}$ \\
Thermal Conductivity normal & 0.7 & 10 & $\mathrm{~W} / \mathrm{m} \cdot \mathrm{K}$ \\
Density & 3720 & $1300-1500$ & $\mathrm{~kg} / \mathrm{m}^{3}$ \\
Mass Heat Capacity & 1726 & 810 & $\mathrm{~J} / \mathrm{kg} \cdot \mathrm{K}$ \\
Battery Capacity & 65 & - & $\mathrm{Ah}$ \\
\hline
\end{tabular}

The cells were machined to accommodate three T-type thermocouple probes each (RS PRO, SS probe, $3 \mathrm{~mm}$ diameter, $150 \mathrm{~mm}$ length, $\pm 0.5^{\circ} \mathrm{C}$ ) and one polyimide (Kapton ${ }^{\circledR}$ ) flexible heater (Omega KHLVA-105, $7.8 \mu$ m thickness, $10 \mathrm{~W} / \mathrm{in}^{2}$, $50 \mathrm{~W}$ ), respectively. The three heaters allow to replicate the heat generation rate profile of the cells depending on their utilization. They are powered by a programmable power supply (TENMA 72$2710,30 \mathrm{~V}, 5 \mathrm{~A}$ ), which is controlled by a bespoke LabVIEW software. All thermocouples underwent a five-point calibration procedure, so the factory precision of $\pm 0.5{ }^{\circ} \mathrm{C}$ typical of T-type thermocouples could be retained.

The LHP used in the present experimental campaign had wick, evaporator envelope and piping made in copper, with the exception of the stainless steel hydraulic unions (Swagelok). The LHP evaporator was obtained from Thercon, Russia, and the rest of the LHP was completed in-house. This was then instrumented with a pressure transducer (Omega PXM319, 0-7 bar range, 0.25\% FS BSL accuracy) fitted directly in the vapour line and 6 T-type thermocouples measuring the temperature of the external surface of the copper pipes, as shown in Figure 4. It was chosen not to measure the fluid temperature directly to favour the simplicity and robustness of the design, without risking the introduction of any additional leakage source (a practice already adopted in [29]). The selected condenser configuration is a tube in tube heat exchanger, where the LHP tube is surrounded by another copper pipe connected to a thermal bath (Fisherbrand ${ }^{\mathrm{TM}}$ Isotemp 5150 R28, cooling capacity $500 \mathrm{~W}$ ) running DI water. The geometry of the utilized LHP is detailed in Table 3.

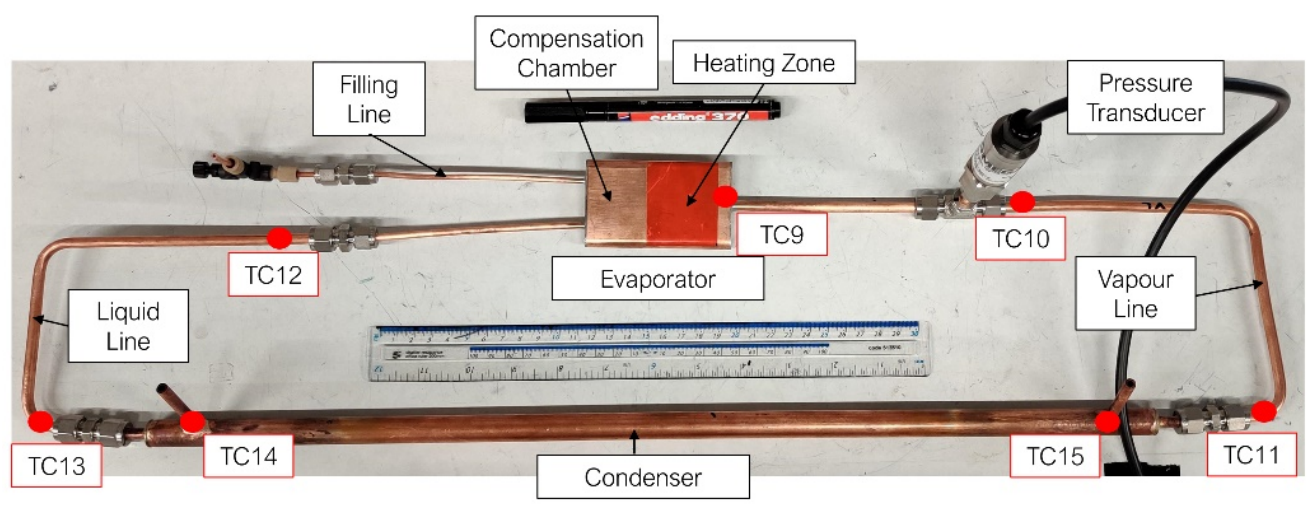

Figure 4. Copper/copper LHP used in the present investigation noted with parts description and thermocouple numbering and positioning. 
Table 3. Geometry of the LHP used in the present investigation (all parts are made in copper).

\begin{tabular}{cccc}
\hline Part & & Value & Units \\
\hline Condenser & ID/OD & $4.4 / 6$ & $\mathrm{~mm}$ \\
HEX & ID/OD & $15 / 11$ & $\mathrm{~mm}$ \\
& Length & 580 & $\mathrm{~mm}$ \\
\hline Liquid & ID/OD & $4.4 / 6$ & $\mathrm{~mm}$ \\
Line & Length & 390 & $\mathrm{~mm}$ \\
\hline Vapour & ID/OD & $4.4 / 6$ & $\mathrm{~mm}$ \\
Line & Length & 400 & $\mathrm{~mm}$ \\
\hline Wick & Thickness & 8 & $\mathrm{~mm}$ \\
& Width & 45 & $\mathrm{~mm}$ \\
& Length & 50.5 & $\mathrm{~mm}$ \\
& Porosity & $45 \%$ & $\mu \mathrm{m}$ \\
\hline Vapour & Pore Size & 7.3 & $\mathrm{~mm}$ \\
Grooves & Radius & 1.5 & - \\
& N & 9 & $\mathrm{~mm}$ \\
\hline \multirow{2}{*}{ Evaporator } & Length & 43 & $\mathrm{~mm}$ \\
Shell & Thickness & 1 & $\mathrm{~mm}$ \\
& Width & 50 & $\mathrm{~mm}$ \\
\hline \multirow{2}{*}{ Compensation } & Length & 84 & $\mathrm{~mm}$ \\
Chamber & Thickness & 8 & $\mathrm{~mm}$ \\
& Width & 50.5 & $\mathrm{~mm}$ \\
\hline & Length & 24 & \\
\hline
\end{tabular}

Vacuum conditions are paramount for correct operation of two-phase passive devices such as the LHP. When vacuum conditions are not sustained, it leads to generation of non-condensable-gases (NCG), which alter the operational behaviour of the LHP. The LHP was leak-tested with a helium mass spectrometer leak detector (Agilent Technologies, VS MD15). The leak rate was measured to be $4.6 \cdot 10^{-10} \mathrm{mbar} / \mathrm{L} \cdot \mathrm{s}$. It was evacuated by means of a two-stage vacuum pump system, comprising of a volumetric scroll pump (Boc Edwards XDS35i) and a turbomolecular pump (Boc Edwards EXT255Hi). The vacuum level obtained with this system was $2.1 \cdot 10^{-5}$ mbar. Finally, Figure 5 shows an image of the entire test set-up.

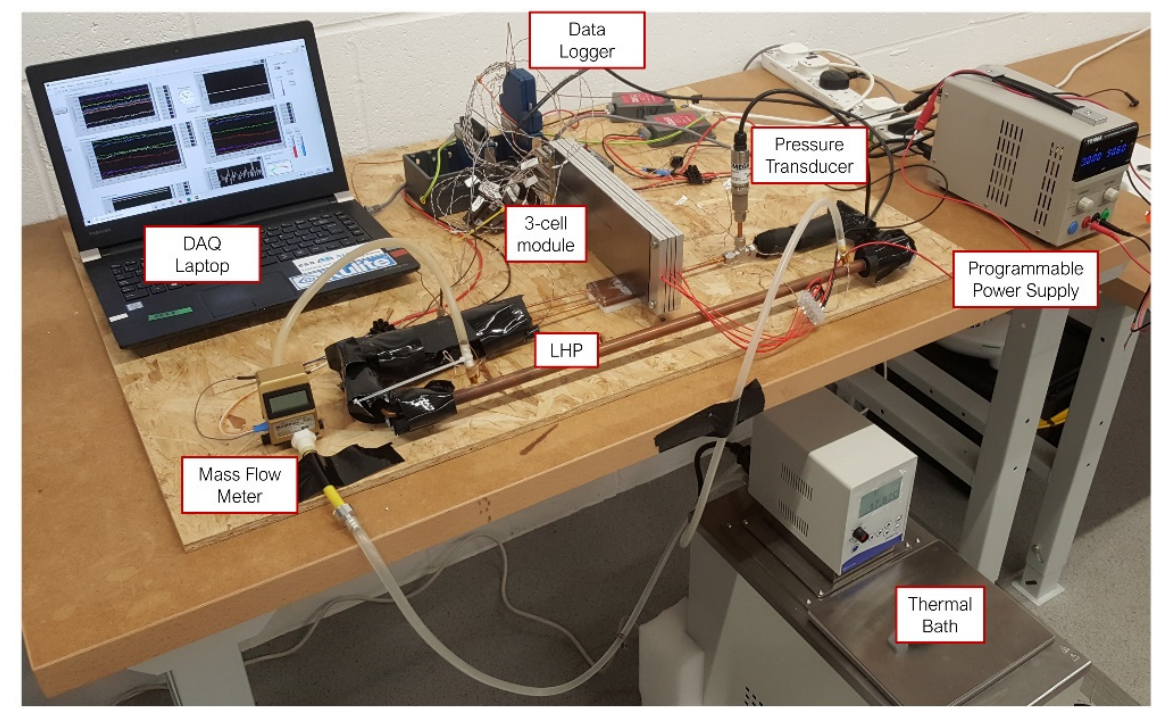

Figure 5. Experimental Set-up used for this investigation. 
As shown in Figure 5, and from the data displayed in Tables 1 and 2, the disparity between the footprint of the module and the heating zone of the evaporator is evident. This is due to the fact that the LHP evaporator geometry was bound by the manufacturer availability. However, although this factor negatively affects the cooling capability of this particular experimental demonstrator design, it does not impede the studying of the feasibility of the TMS system nor the validation of the numerical model (which was the primary aim of the experimental demonstrator).

\section{Novec $^{\mathrm{TM}} 649$ Selection Rationale}

The working fluid selection is of paramount important not only for the performance of the TMS, but also to ensure safety of the system and passengers, in addition to not presenting a threat to the environment. As such, Novec ${ }^{\mathrm{TM}} 649$ was chosen as the working fluid, as it has the following characteristics:

- It is non-toxic, so it will not harm passengers in case of leakage and presents advantages for production, as it does not require precautions for handling;

- It is non-flammable, as the TMS should not add any risk of incrementing a failure, not only in cases of leaks, but also in disruptive cases (such as accidents, crashes);

- It is inert and dielectric, so in case of leakage and contact with the battery cells, the working fluid will not cause a short-circuit;

- It has a global warming potential (GWP) value of 1 and ozone depletion potential (ODP) of 0 , which are unparalleled values compared to other refrigerants and heat transfer fluids used in the automotive sector. Moreover, regulation No. 517/2014 of the European Parliament prevents the use of refrigerants with GWP higher than 150;

- It has a low freezing point of $-108{ }^{\circ} \mathrm{C}$, allowing it to be used in cold climates without the risk of damage to the LHP;

- Its boiling point of $49^{\circ} \mathrm{C}$ is lower than other standard working fluids used in twophase passive devices, which is makes it more suitable at keeping the cell temperature in the desired range.

Table 4 compares standard working fluids used in LHPs and EV thermal management systems, highlighting the reason why the authors believe that the Novec ${ }^{\mathrm{TM}} 649$ is an excellent candidate for the application.

Table 4. How Novec ${ }^{\mathrm{TM}} 649$ compares against other standard LHP and automotive working fluids.

\begin{tabular}{|c|c|c|c|c|}
\hline Fluid & $\begin{array}{l}\text { Boiling } \\
\text { Point } \\
{\left[{ }^{\circ} \mathrm{C}\right]}\end{array}$ & $\begin{array}{l}\text { Freezing } \\
\text { Point } \\
{\left[{ }^{\circ} \mathrm{C}\right]}\end{array}$ & Application & Cons Compared to Novec ${ }^{\mathrm{TM}} 649$ \\
\hline Novec $^{\mathrm{TM}} 649$ & 49 & -108 & This work & \\
\hline Water & 100 & 0 & $\begin{array}{l}\text { EV [30,31]; } \\
\text { LHP [32] }\end{array}$ & $\begin{array}{l}\text { Freezing at } 0^{\circ} \mathrm{C} \text { with expansion that } \\
\text { can break wick and piping of LHP; } \\
\text { electrical conductor }\end{array}$ \\
\hline Ethanol & 78 & -114 & LHP [33] & Toxic and flammable \\
\hline Ammonia & -33 & -77 & LHP [34] & $\begin{array}{l}\text { High Vapour Pressure }\left(10 \text { bar@25 }{ }^{\circ} \mathrm{C}\right) ; \\
\text { toxic and flammable }\end{array}$ \\
\hline Acetone & 56 & -95 & LHP [35] & Toxic and flammable \\
\hline R134a & -26 & -103 & EV [36] & $\begin{array}{l}\text { High GWP of } 1430 ; \text { boiling point too } \\
\text { low }\left(<20^{\circ} \mathrm{C}\right)\end{array}$ \\
\hline Novec $^{\text {TM }} 7000$ & 34 & -123 & EV $[16,37]$ & High GWP of 420 \\
\hline Ethylene Glycol & 197 & -13 & EV $[20,38]$ & Toxic and flammable \\
\hline R1234yf & -30 & -150 & EV [39] & $\begin{array}{l}\text { Mildly flammable per ASTM E-681-04; } \\
\text { boiling point too low }\left(<20^{\circ} \mathrm{C}\right)\end{array}$ \\
\hline
\end{tabular}


As mentioned in the Introduction, this work carries out a comparison between the results obtained using ethanol and Novec $^{\mathrm{TM}}$ 649, together with an assessment of the performance of the proposed TMS design running Novec ${ }^{\mathrm{TM}} 649$ over different C-Rates.

\section{Experimental Results and Discussion}

\subsection{Comparison between Novec ${ }^{\mathrm{TM}} 649$ and Ethanol}

To compare the performance of Novec ${ }^{\mathrm{TM}}$ 649, Ethanol is chosen as the benchmark fluid since it has already proven to be a well-performing working fluid both in LHP standalone applications as well as LHP applied to EV. The comparison is carried out over a bespoke highway-fast charging-highway $(\mathrm{HFCH})$ driving cycle (detailed in Table 5), involving a section of highway driving followed by a challenging fast charging section and finally concluding with another identical highway driving section until complete depletion of the charge. The choice of a bespoke driving cycle was motivated by the fact that standard driving cycles (such as WLTP) are mainly used to test and evaluate $\mathrm{CO}_{2}$ and other pollutant emissions and fuel consumption, while they do not stress the vehicle for long enough periods to result in a significant depletion of the charge, nor do they include a section for fast charging. In Table 5, it is shown that the fast charge section lasts for only 10 min and reaches a maximum c-rate of $4^{\circ} \mathrm{C}$, which is higher than the current state of the art [40]. The C-Rate is defined as the current through the battery divided by the theoretical current which will completely deplete the cell nominally rated capacity in one hour, e.g., a $1 \mathrm{C}$ C-rate will charge/discharge the cell in one hour, a $2 \mathrm{C}$ in half an hour, a $0.5 \mathrm{C}$ in two hours and so on. During fast charge, the state of charge (SOC) goes from $20 \%$ to $80 \%$, as this is standard practice in automotive applications due to safety limitations [40]. SOC is a quantity that denotes the capacity that is currently available as a function of the rated capacity, defined as the ratio of the available capacity divided by the maximum possible charge that can be stored in the cell [41].

Table 5. Highway-Fast Charge-Highway (HFCH) driving cycle C-rates and SOC. Negative C-Rate indicates the discharge period (hence with negative current). The two sections with 0 c-rate stand to represent the actual stops that the user would take before and after charging the vehicle.

\begin{tabular}{ccc}
\hline C-Rate & Duration (minutes) & Final SOC \\
\hline-1 & 48 & $20 \%$ \\
0 & 1 & $40 \%$ \\
4 & 3 & $59 \%$ \\
3.75 & 3 & $77 \%$ \\
3.5 & 3 & $81 \%$ \\
2.5 & 1 & - \\
0 & 1 & $20 \%$ \\
\hline
\end{tabular}

Following the presentation of the general results of the HFCH driving cycle tests, a comparison is made of the average cell temperature in the two cases. As already presented in Figure 3, thermocouples numbered from zero to eight are measuring the temperatures of the module cells, whereas thermocouples numbered from nine to fifteen are measuring the temperatures of the LHP and heat exchanger.

One notices that the cell temperature is above the threshold required by the pack requirement, as maximum temperatures in the middle and side cells of the module are $57^{\circ} \mathrm{C}$ and $53{ }^{\circ} \mathrm{C}$ for the ethanol case. This is due to the mismatch in available surface between the battery module and the heating zone of the LHP evaporator, as shown in Tables 2 and 3, as the latter was bound by the manufacturer availability. It has been already proven that if the heating zone of the LHP evaporator has a size close to the battery module footprint, the maximum cell temperature drops considerably below $40^{\circ} \mathrm{C}$ [17]. 
The average temperature spread (i.e., maximum temperature difference over a single cell) over the three cells is $0.7^{\circ} \mathrm{C}$, which is below the threshold of $3-5^{\circ} \mathrm{C}$ set by the cell requirement. Furthermore, the difference between the temperature of cell $2(\mathrm{TC} 3,4,5)$ and the cell $3(\mathrm{TC} 6,7,8)$ is $4.5^{\circ} \mathrm{C}$, whereas the temperature difference between the cell 2 and the cell $1(\mathrm{TC} 0,1,2)$ is $1.8^{\circ} \mathrm{C}$. This difference is due to cell 1 being without the graphite sheet, which was a design choice to investigate the effect of graphite on the side cells of the modules. It shows that in both cases, with respect to the middle cell, the proposed design respects the module thermal requirement as well (i.e., $\Delta \mathrm{T}$ between the cell to be less than $5^{\circ} \mathrm{C}$ ). Moreover, it shows that having graphite on both side of the cell reduces the maximum temperature at the end of fast charge by $1.8^{\circ} \mathrm{C}$, compared to having graphite only on one side and free convection on the other ( $\Delta \mathrm{T}$ between cell 1 and cell 2$)$.

Looking at the test results obtained with ethanol presented in Figure 6, one can notice that the onset of the predominant boiling condition typical of the LHP, the so-called startup, happens well into the fast charging section (around $3500 \mathrm{~s}$ ), as shown by the sudden increase of the temperature at the inlet of the condenser (orange line-TC11) and the decrease of the temperature at the outlet of the condenser (green line-TC13) and at the end of the liquid line back into the evaporator (yellow line-TC12). These temperature trends mean that the vapour has reached the condenser to reject the heat (increase of orange line), and condensation occurs, creating cooler subcooled liquid that exits the condenser (green line) and reaches the evaporator by the end of the liquid line (yellow line).

However, the start-up took place halfway through the fast charging period, which is not optimal. In fact, the comparison shown in Figure 7 between heat generated by the module and heat received by the LHP (obtained from the simulations in [17]), shows a great difference due to heat being stored as heat capacity in the cell material as a result of the strongly transient nature of the driving cycle. As such, a design where the LHP starts sooner or at lower power levels would be beneficial.
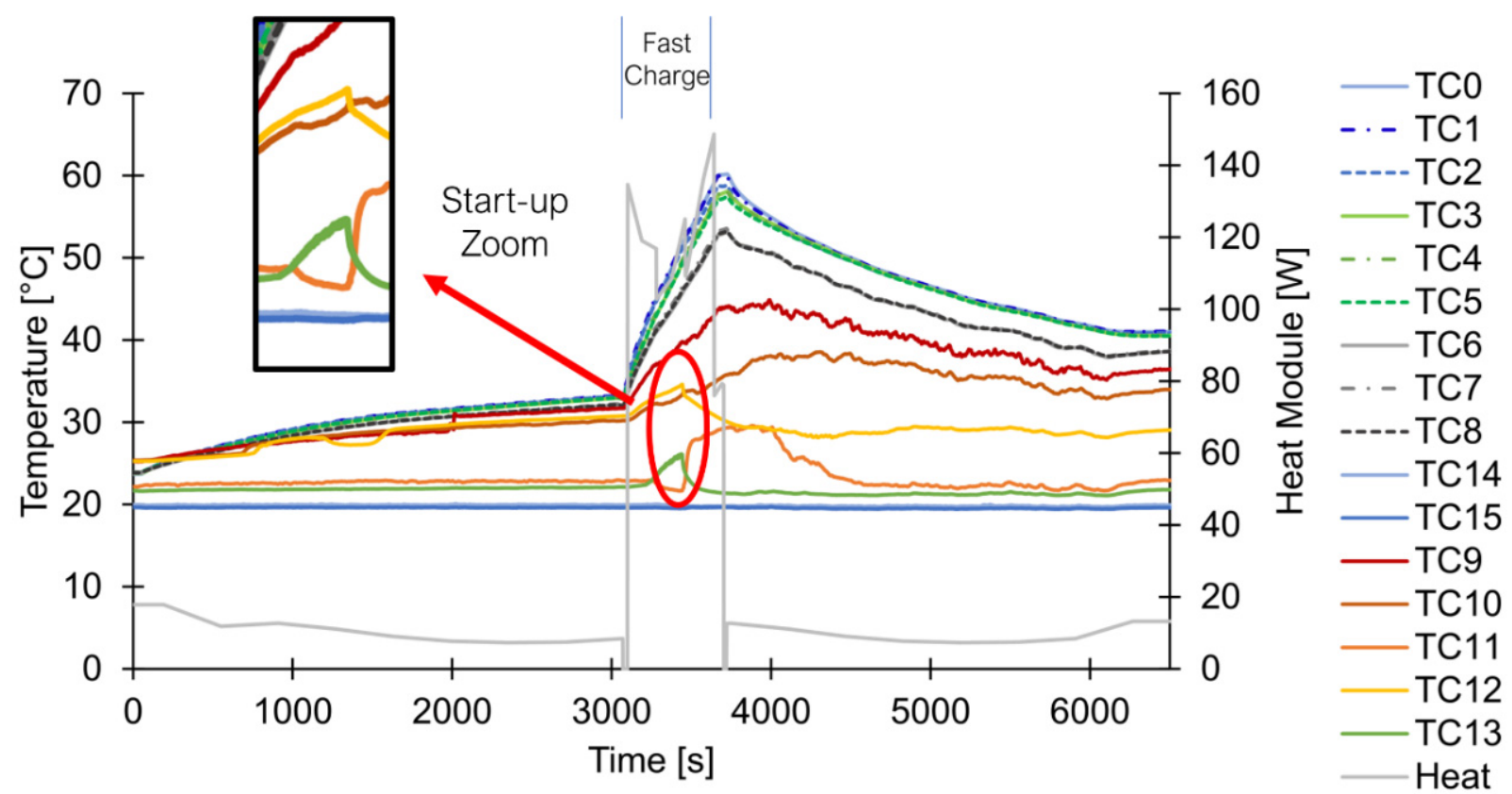

Figure 6. Test results during a HFCH driving cycle using Ethanol as working fluid. 


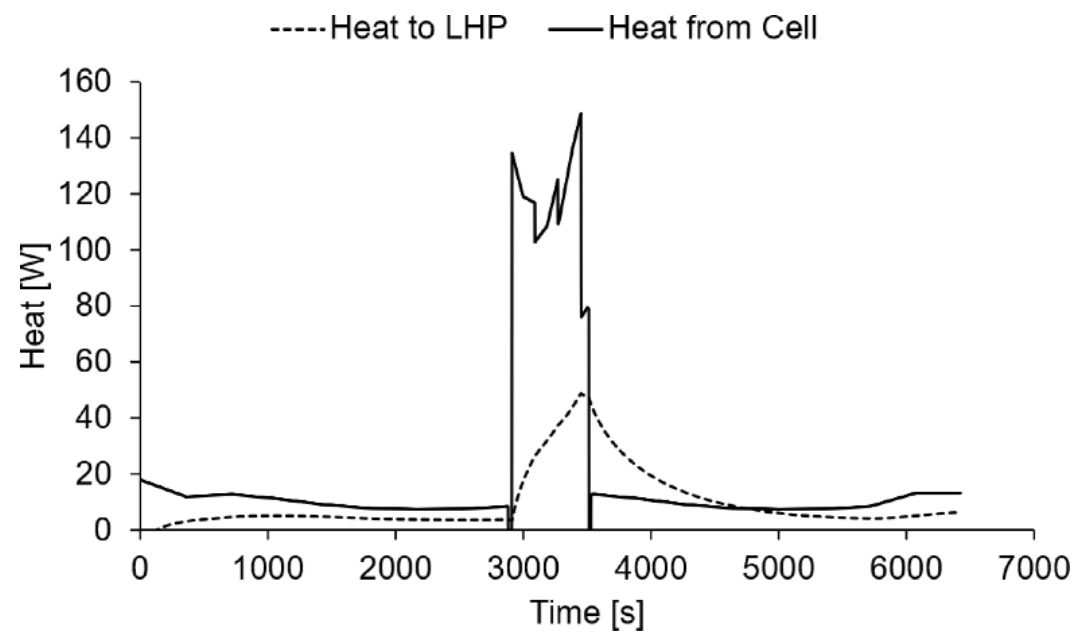

Figure 7. Comparison between heat generated by the module and received by the LHP during the $\mathrm{HFCH}$ driving cycle [17].

In Figure 8, the results of the test carried out with Novec ${ }^{\mathrm{TM}} 649$ as working fluid are presented. The sudden increase of the temperature of the condenser inlet (orange line-TC11) denotes that the start-up is happening as soon as the fast charge section is initiated, which is a clear improvement from the ethanol case. This behaviour was expected since Novec ${ }^{\mathrm{TM}} 649$ has lower boiling point, latent heat of vaporisation and mass specific heat with respect to ethanol (Table 6).

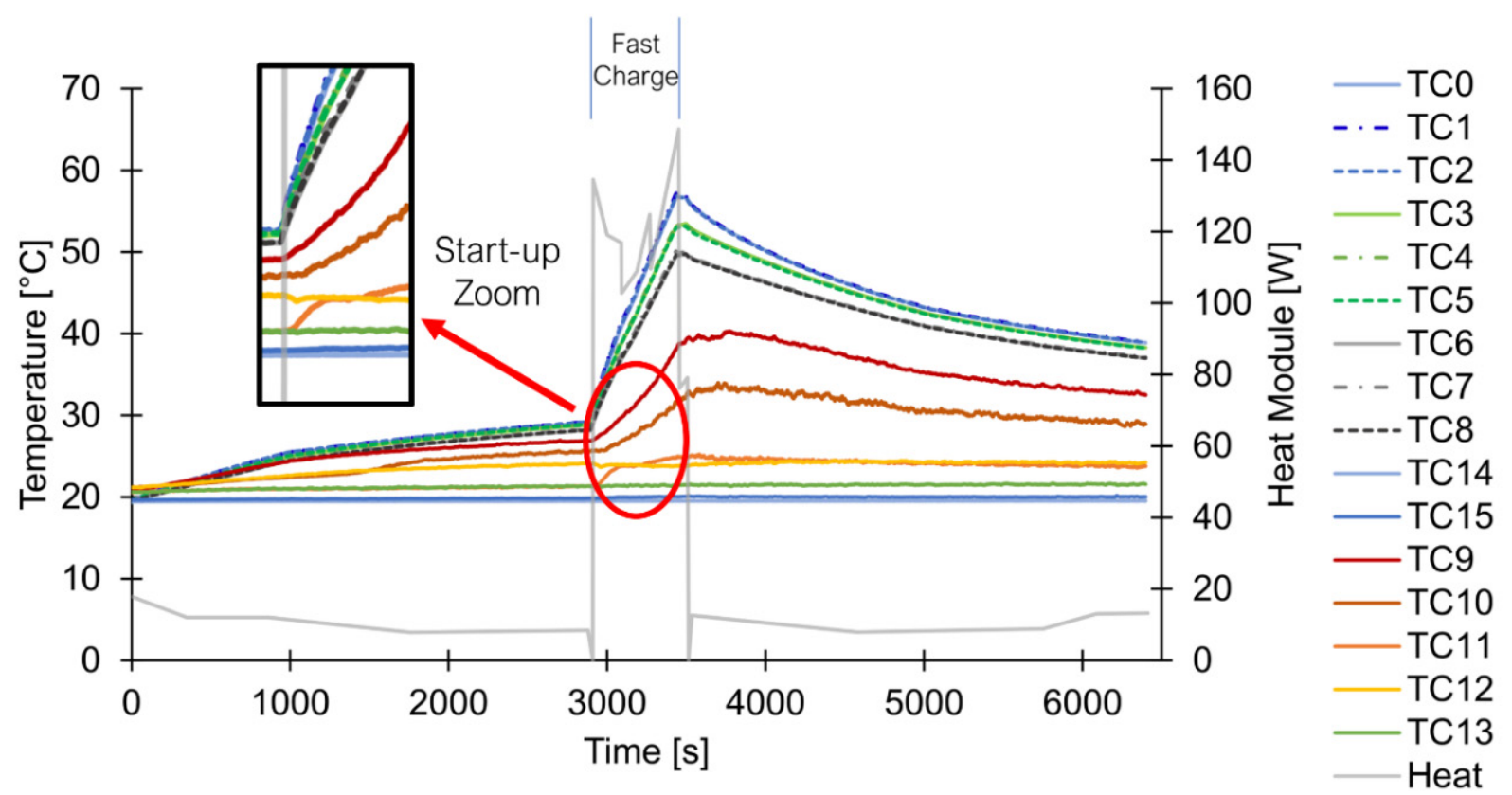

Figure 8. Test results during a HFCH driving cycle using Novec ${ }^{\mathrm{TM}} 649$ as working fluid.

Looking at the difference between the two fluids, their main physical properties are presented in Table 6. Considering the lower boiling point, the significantly lower latent heat of vaporisation and specific heat, one can expect that the LHP start-up while running with Novec ${ }^{\mathrm{TM}} 649$ would happen at lower temperatures and heat inputs than with ethanol. 
Table 6. Key physical properties of ethanol and $\mathrm{Novec}^{\mathrm{TM}}$ 649. All properties are evaluated at $20^{\circ} \mathrm{C}$.

\begin{tabular}{ccc}
\hline & Ethanol & Novec $^{\mathrm{TM}} \mathbf{6 4 9}$ \\
\hline Boiling Point $\left[{ }^{\circ} \mathrm{C}\right]$ & 78 & 49 \\
Freezing Point $\left[{ }^{\circ} \mathrm{C}\right]$ & -114 & -108 \\
Density $[\mathrm{kg} / \mathrm{m}]$ & 804 & 1600 \\
Viscosity $[\mathrm{mPa} \cdot \mathrm{s}]$ & 1.19 & 0.64 \\
Thermal Conductivity $[\mathrm{W} / \mathrm{m} \cdot \mathrm{K}]$ & 0.17 & 0.06 \\
Latent Heat of Vaporisation $[\mathrm{kJ} / \mathrm{kg}]$ & 945 & 88 \\
Specific Heat $[\mathrm{J} / \mathrm{kg} \cdot \mathrm{K}]$ & 3023 & 1103 \\
Surface Tension $[\mathrm{N} / \mathrm{m}]$ & 0.022 & 0.011 \\
Saturation Pressure $[\mathrm{bar}]$ & 0.062 & 0.400 \\
\hline
\end{tabular}

Figure 9 presents a comparison between the average cell temperature obtained using the two working fluids. It is worth pointing out that the two tests were performed in different lab temperatures $\left(20^{\circ} \mathrm{C}\right.$ for the Novec ${ }^{\mathrm{TM}} 649$ test and $25^{\circ} \mathrm{C}$ for the ethanol test), so in order to effectively compare the two cases, the temperature is expressed as $\Delta \mathrm{T}$ from the ambient temperature. Results show that the two fluids perform in a similar fashion, with maximum temperature at the end of fast charging being different by only $0.7^{\circ} \mathrm{C}$ in the two cases. Ethanol looks slightly better at reducing the temperature in the final highway driving section, giving a final temperature of $2.2^{\circ} \mathrm{C}$ lower than the other fluids. However, the important message of the comparison graph of Figure 9 is that using Novec $^{\mathrm{TM}} 649$ provides a non-flammable, environmentally friendly and non-toxic alternative to ethanol, without a significant decrease in thermal performance.

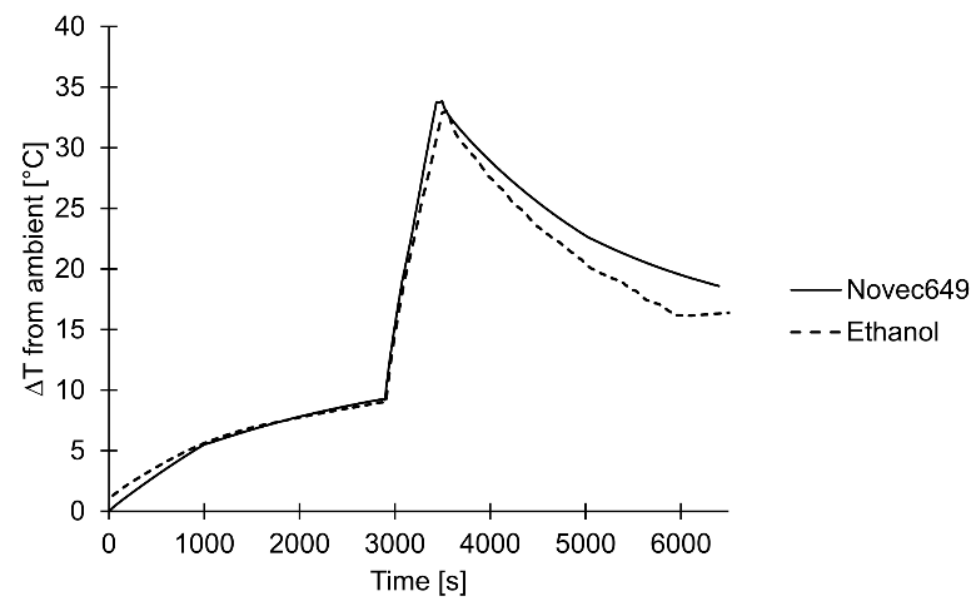

Figure 9. Average cell temperature comparison over the HFCH obtained using the LHP with Novec ${ }^{\mathrm{TM}}$ 649 or ethanol as working fluids.

\subsection{Assessment of TMS with Novec ${ }^{\mathrm{TM}} 649$ during Different C-Rates}

The previous section showed that there is no significant difference in maximum temperature reduction between the two fluids investigated. Therefore, there is enough confidence to proceed with the investigation on Novec ${ }^{\mathrm{TM}} 649$ as a working fluid. This section presents a study assessing the potential for using this design as an effective way to contain the temperature during fast charge. The tests have been carried out supplying the cells with power equivalent to fast charge cycle with three different c-rates, namely 1C, $2 \mathrm{C}$ and $3 \mathrm{C}$, from $20 \%$ to $80 \%$ SOC, as this is the standard practice due to safety limitations [40]. Figure 10 presents the power profile of the modules depending on the c-rate, showing the necessity of using a programmable power supply to replicate the transient heat generation rate typical of the cells. Thus, as shown in Table 7, these fast-charging profiles last for 36 min for 1C-Rate, $18 \mathrm{~min}$ for 2C-Rate and $12 \mathrm{~min}$ for 3C-Rate. 


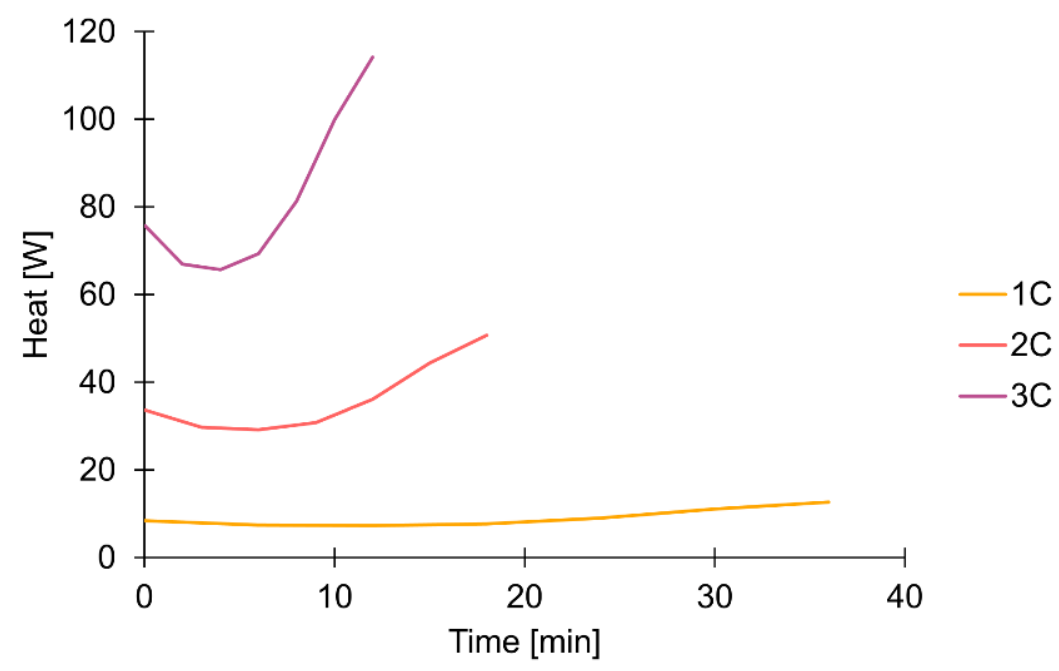

Figure 10. Power vs. time (in minutes) profiles of the different C-rates used in this investigation. These figures refer to a $20 \%$ to $80 \%$ SOC charge.

Table 7. Duration and average heat generation rate of single cell and module, considering a fast charge from $20 \%$ to $80 \%$ depending on the different C-Rates.

\begin{tabular}{cccc}
\hline C-Rate & $\begin{array}{c}\text { Charge Times } \\
\mathbf{2 0 - 8 0 \%} \text { SOC }\end{array}$ & $\begin{array}{c}\text { Heat Cell } \\
{[W]}\end{array}$ & $\begin{array}{c}\text { Heat 3Cell } \\
\text { Module [W] }\end{array}$ \\
\hline 1C & $36 \mathrm{~min}$ & 3 & 9 \\
$2 \mathrm{C}$ & $18 \mathrm{~min}$ & 12 & 36 \\
$3 \mathrm{C}$ & $12 \mathrm{~min}$ & 27 & 81 \\
\hline
\end{tabular}

At the moment of writing, the state of the art is represented by the Porsche Taycan, which provides a maximum charging rate of $3 \mathrm{C}$, whereas for the remaining EVs the charge rate is limited to $1-1.5 \mathrm{C}$ [40]; hence why it was deemed appropriate to test the solution presented in this work against the state of the art condition. All the below reported tests were carried out at an ambient temperature of $20^{\circ} \mathrm{C}$.

Figure 11 shows the temperature and pressure trends when the cells are subjected to a 1C charge profile, hence an average total heat generated by the module of $9 \mathrm{~W}$. As shown by the temperature of the LHP nodes, no start-up is taking place, indicating in this case that the heat provided to the evaporator is not sufficient or that the heat is not supplied for a long enough time interval. The maximum temperature reached by the LHP evaporator (TC9) was $25.1^{\circ} \mathrm{C}$. However, the maximum temperature of the cells is $28.4^{\circ} \mathrm{C}$ (as also provided in Table 8 ) so this condition remains within the optimal operating temperature range of the cell. This shows that, for the charge time only, $1 \mathrm{C}$ fast charge is a condition that does not require bespoke TMS.

Table 8. Comparison of maximum cell temperatures during the fast charge tests, together with the maximum temperature difference across the module. Results are provided with the uncertainty associated with calibrated T-type thermocouples $\left( \pm 0.5^{\circ} \mathrm{C}\right.$ and $0.7^{\circ} \mathrm{C}$ for the $\Delta$ measurement).

\begin{tabular}{ccccc}
\hline C-Rate & Cell 1 $\left[{ }^{\circ} \mathbf{C}\right]$ & Cell 2 $\left[{ }^{\circ} \mathbf{C}\right]$ & Cell 3 $\left[{ }^{\circ} \mathbf{C}\right]$ & $\Delta\left[{ }^{\circ} \mathbf{C}\right]$ \\
\hline 1C & $28.4 \pm 0.5$ & $28.1 \pm 0.5$ & $27.5 \pm 0.5$ & $0.9 \pm 0.7$ \\
2C & $36.3 \pm 0.5$ & $34.8 \pm 0.5$ & $33.3 \pm 0.5$ & $3.0 \pm 0.7$ \\
$3 C$ & $46.4 \pm 0.5$ & $43.5 \pm 0.5$ & $41.0 \pm 0.5$ & $5.4 \pm 0.7$ \\
\hline
\end{tabular}




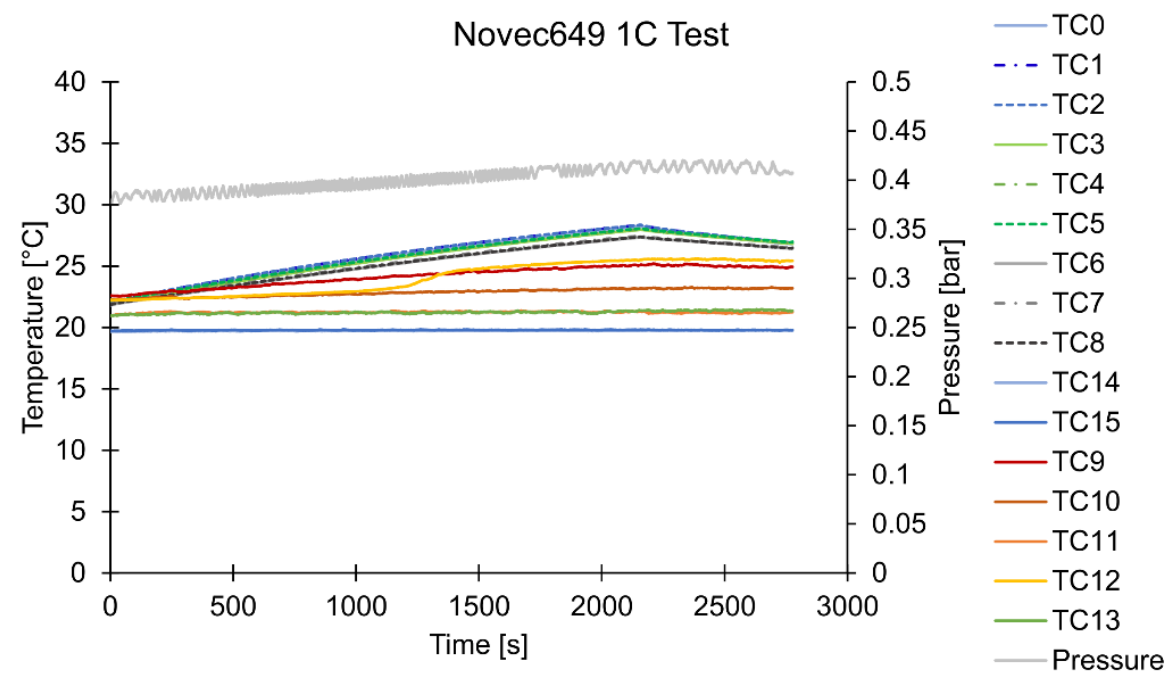

Figure 11. Fast Charging test results with $1 \mathrm{C}$.

Nonetheless, one of the aims of the present work is to allow for faster charge times, so a $2 \mathrm{C}$ fast charge test is carried out, hence halving the charge time compared to the previous case. In the results shown in Figure 12, the LHP start-up takes place around $850 \mathrm{~s}$ as indicated by the increase in temperature of the vapour line inlet (TC10) followed by the increase in the condenser inlet (TC11). The temperature of the evaporator (TC9) at start-up is $25.4{ }^{\circ} \mathrm{C}$, thus a bit higher than the maximum reached during the $1 \mathrm{C}$ test. Moreover, another clear indicator is the pressure trend (grey line) that flattens and decreases ever so slightly to indicate the depressurisation left by a departing bubble, as indicated by [42].

Due to the much higher heat generation rate that the cell is providing (four times as much as the $1 \mathrm{C}$ case), the conditions are favourable to the onset of boiling and, consequently, for the fluid to circulate in a preferential direction. In fact, one can notice from Figure 11 that the temperature of the outlet of the liquid line (TC12) is not increasing, rather it decreases following the increase of the condenser inlet, thus proving that the condensed liquid is flowing back to the evaporator. As proof that this behaviour is due to the start-up, Figure 12 shows that when the power is subtracted from the evaporator, the trends of TC12 and TC10 are reversed.

During this test, maximum average temperature reached by the cells was $36.3{ }^{\circ} \mathrm{C}$ degrees, while its SOC would reach $80 \%$ in $18 \mathrm{~min}$.

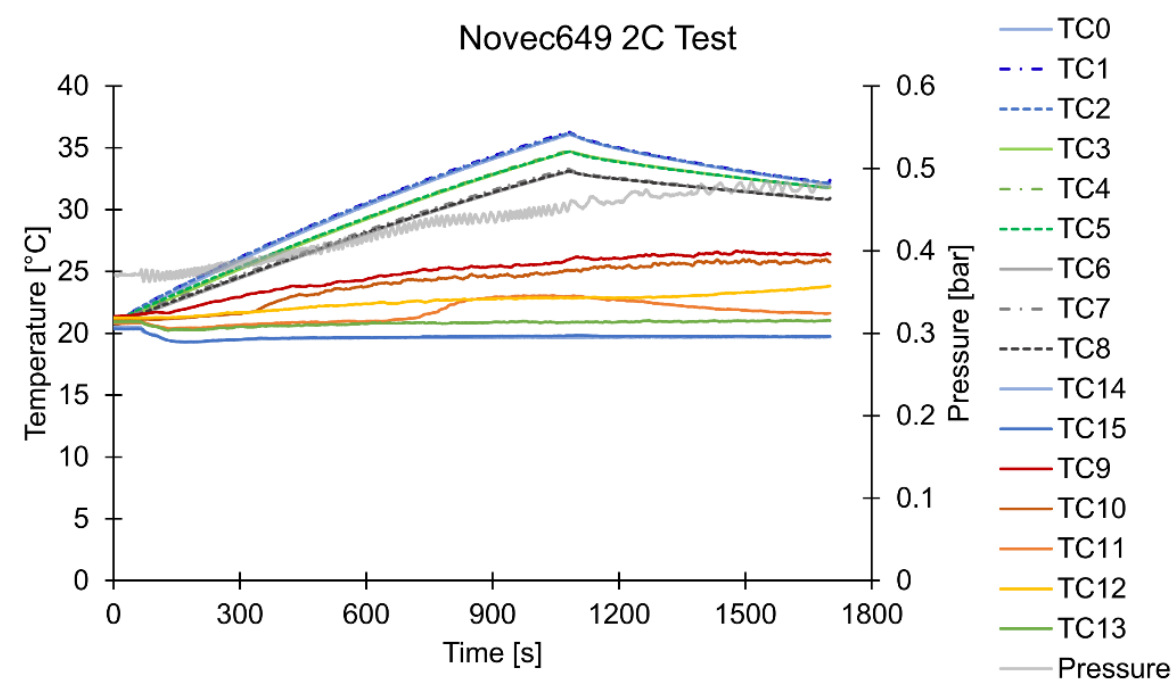

Figure 12. Fast Charging test results with $2 \mathrm{C}$. 
Finally, the fast charge test with $3 \mathrm{C}$ is presented in Figure 13. Following the increased cell heat generation rate, start-up happens sooner than in the other two cases, around $580 \mathrm{~s}$, noticeable by the small semi-steady section of the pressure trend. The temperature of the evaporator (TC9) at start-up is $25.8^{\circ} \mathrm{C}$. Hence, looking at the LHP start-up temperatures $\left(25.4{ }^{\circ} \mathrm{C}\right.$ for $2 \mathrm{C}$ test and $25.8^{\circ} \mathrm{C}$ for $3 \mathrm{C}$ test), it looks like that in the $1 \mathrm{C}$ case the LHP does not reach the required temperature for start-up ( $\max T e m p$ of $25.1^{\circ} \mathrm{C}$ ) in the allotted test time.

In the $3 \mathrm{C}$ test case the maximum average temperature of the cell was $46.4{ }^{\circ} \mathrm{C}$, at the end of a fast charge profile that would allow $80 \%$ of the SOC to be reached in only $12 \mathrm{~min}$.

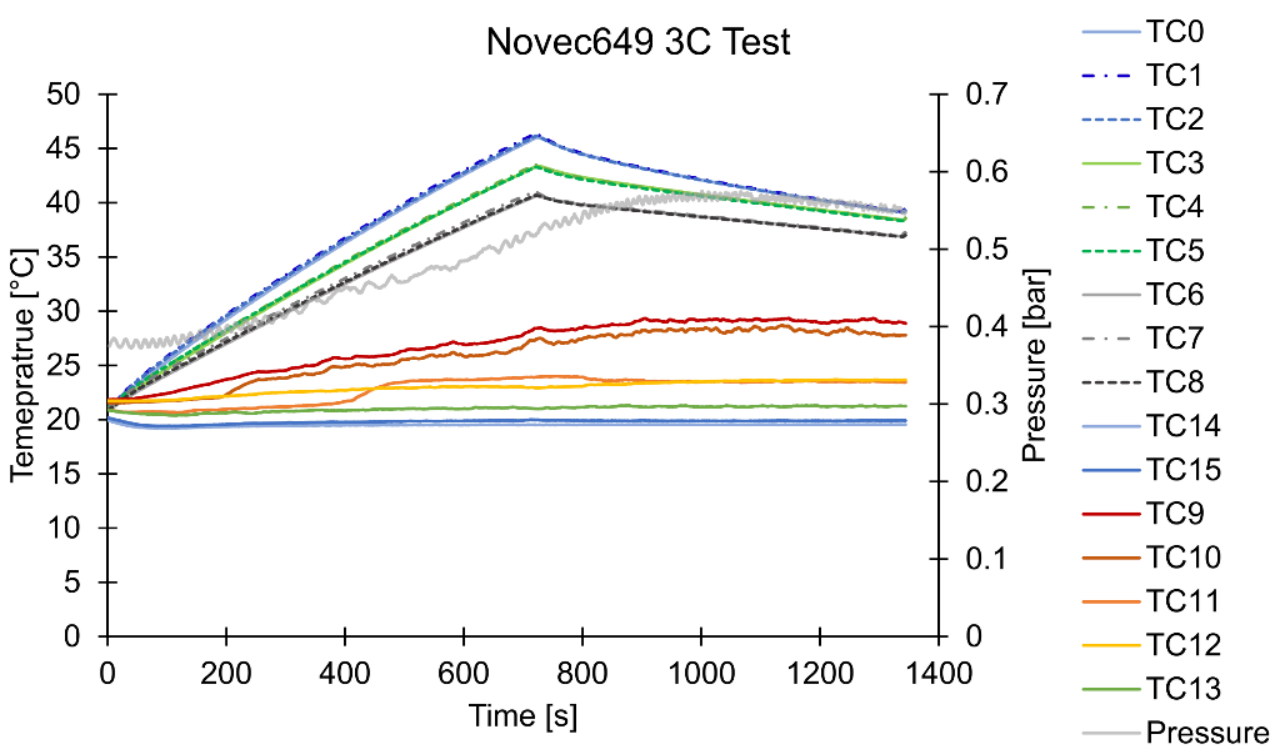

Figure 13. Fast Charging test results with $3 \mathrm{C}$.

Looking at the pressure trends in Figures 11-13 one can notice how it follows the trend of the vapour line temperature, as expected. Pressure values are always inside a comfortable safe $0.4-0.6$ bar range, due to the low temperature of the working fluid. Further confirmation of the importance of the thermal mass of the cells is given by the fact the pressure keeps on increasing even after the nullification of the heating power at the cells. In fact, heat keeps on being transferred to the LHP evaporator for a few minutes, before the pressure starts to decrease. This means that the TMS proposed in this work will keep on removing the excess heat from the cells even after the fast charge section, ideally even while the vehicle has resumed its journey.

In sum, Figure 14 shows the maximum temperature of each cell during the fast charge experiments. In addition, Table 8 shows the numerical results, with the respective errors, from the direct temperature measurements $\delta$ and from the indirect $\Delta$ calculation $\left(\sqrt{\delta^{2}+\delta^{2}}=\sqrt{2} \delta\right)$. One can see that the maximum temperature during the $3 \mathrm{C}$ fast charge is above the optimal threshold of $40{ }^{\circ} \mathrm{C}$, but nonetheless it inside the acceptable range $\left(<50{ }^{\circ} \mathrm{C}\right)$ as well as being below the safety threshold of $60^{\circ} \mathrm{C}$, despite the LHP possessing a much smaller active heating zone than required. In addition, Figure 14 shows that the temperature difference between the cell surrounded by graphite (cell 2) and the one with a naked side (cell 3), increases with the C-Rate, suggesting the efficacy of the graphite to increase the thermal efficiency of the BTMS. This indicates the cooling potential of the TMS proposed herein and underlines the need for further investigation by means of a larger, bespoke prototype. Moreover, the temperature spread over the module is inside the requirement at the module level. 


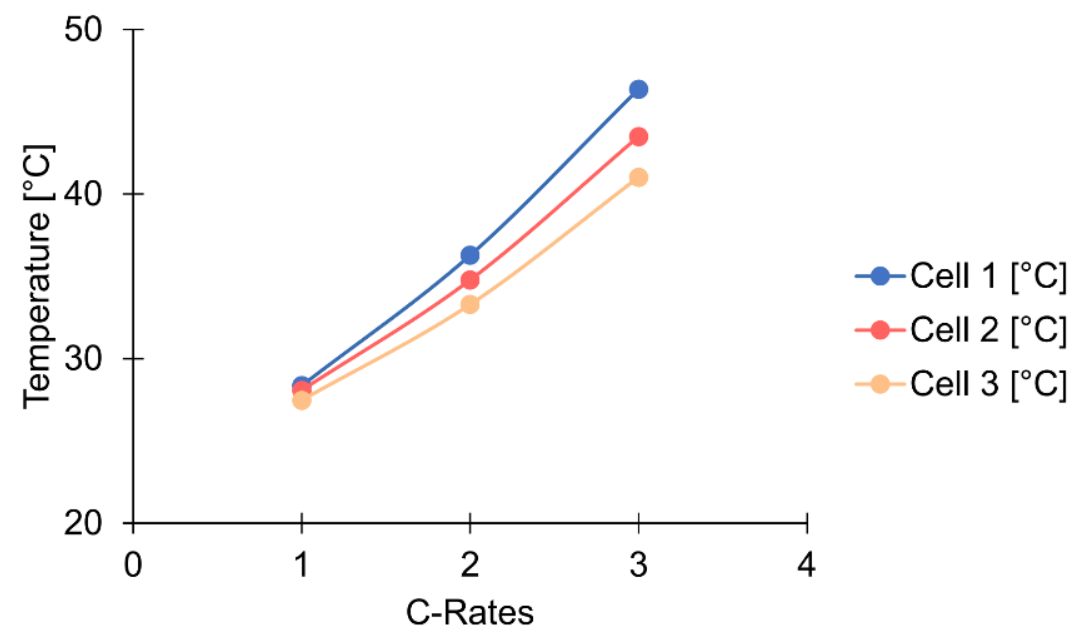

Figure 14. Comparison of the maximum temperature reached by each cell during the fast charge experiments with Novec $^{\mathrm{TM}} 649$. Measures have an accuracy of $\pm 0.5^{\circ} \mathrm{C}$ (T-type thermocouples).

The results prove that Novec $^{\mathrm{TM}} 649$ can be a valuable substitute to standard heat transfer fluids already employed in two-phase applications, and if applied to the proposed design with LHP and graphite sheets, the battery temperature can be contained within acceptable levels, even during aggressive state of the art fast charge scenarios (3C).

\section{Conclusions}

In this work, an alternative to standard battery thermal management system for EVs was provided, both in terms of thermal vector and working fluid. The aim of this work was twofold: firstly, to propose a thermal solution able to allow for fast charging and not affecting the all-electric range of the vehicle; secondly, to identify, implement and test a safe thermal medium with low environmental impact. An LHP was chosen as a main thermal vector to exploit its excellent heat transport capabilities and its passive nature (no parasitic power hence more range). Novec $^{\mathrm{TM}} 649$ was selected as a working fluid because to its outstanding properties of non-flammability, non-toxicity, and low freezing and boiling points. More importantly, it possesses extremely low pollutant factors (GDP $=1$ and ODP $=0$ ). The proposed design comprised a Novec ${ }^{\mathrm{TM}} 649$ filled LHP applied to the bottom of a three-cell module with graphite sheets sandwiched between the cells, allowing for efficient heat transfer in the vertical plane and heat isolation from the transversal plane. The main findings are presented below:

- $\quad$ For the first time an LHP filled with Novec ${ }^{\mathrm{TM}} 649$ as working fluid is utilized and thermally characterized.

- Comparing the results with the same LHP filled with ethanol over a bespoke driving cycle including $4 \mathrm{C}$ fast charge, the cell temperatures when using the two fluids, ethanol and Novec $^{\mathrm{TM}} 649$, in the TMS were very similar; in fact, the maximum temperatures at the end of fast charge differed by only $0.7^{\circ} \mathrm{C}$.

- Ethanol was slightly better in reducing the temperature in the final highway driving section, giving a final temperature $2.2^{\circ} \mathrm{C}$ lower than $\mathrm{Novec}^{\mathrm{TM}} 649$.

- Quicker start-up was achieved while using $\operatorname{Novec}^{\mathrm{TM}} 649$, as the lower boiling point and latent heat of vaporisation compared to ethanol made the LHP start as soon as the fast charge was initiated;

- The proposed TMS running Novec ${ }^{\mathrm{TM}} 649$ was tested for different fast charge cycles, $1 \mathrm{C}, 2 \mathrm{C}$ and $3 \mathrm{C}$, where the maximum temperatures were $28.4{ }^{\circ} \mathrm{C}, 36.3^{\circ} \mathrm{C}$ and $46.4{ }^{\circ} \mathrm{C}$ respectively; these results are below the safety threshold of $60^{\circ} \mathrm{C}$ and very close to the $25-40{ }^{\circ} \mathrm{C}$ optimum window.

- The maximum temperature difference across the cells belonging to the module is $5{ }^{\circ} \mathrm{C} @ 3 \mathrm{C}$ fast charge, which in line with the thermal requirement at the module level; 
moreover, it was proven that graphite improves the cell temperature reduction by almost $21^{\circ} \mathrm{C}$.

These thermal results are very promising, especially considering that, due to manufacturing limitations, the active heating area of the LHP evaporator was much smaller than the battery module footprint, as already mentioned in the manuscript. In fact, even pushing a demanding fast charge cycle in $12 \mathrm{~min}$, the maximum cell temperature still kept below $50{ }^{\circ} \mathrm{C}$. Therefore, the important message of this work is that using this novel LHP-based TMS with Novec ${ }^{\mathrm{TM}} 649$ as working fluid provides a non-flammable, environmentally friendly and non-toxic alternative to classical heat transfer fluid that not only does not provide a noticeable decrease in thermal performance if compared to other standard flammable and/or toxic heat transfer fluid, but is also able to respond to the thermal requirements of the BTMS for EVs.

Author Contributions: Conceptualization, M.B., A.G., N.M., C.R. and M.M.; methodology, M.B.; validation, M.B.; investigation, M.B. and N.M.; resources, M.B., C.R. and M.M.; data curation, M.B.; writing—original draft preparation, M.B.; writing—review and editing, M.B., A.G., N.M. and M.M.; visualization, M.B.; supervision, A.G., N.M., C.R. and M.M.; project administration, M.M.; funding acquisition, A.G., N.M., C.R. and M.M. All authors have read and agreed to the published version of the manuscript.

Funding: This research and the APC were funded by the School of Architecture, Technology and Engineering (University of Brighton), the Advanced Engineering Centre (University of Brighton) and Ricardo plc.

Acknowledgments: The Authors would like to thank $3 \mathrm{M}^{\mathrm{TM}}$ and in particular Ian Kelsall for the fluid sample and the patience in the negotiations. The Authors would like to acknowledge Ricardo plc as well, for the financial support. The Authors would like also to thank the Advanced Engineering Centre and the School of Computing, Engineering and Mathematics at the University of Brighton for the support during the COVID-19 pandemic. Finally, the Authors would like to thank Yury Maidanik and Arkadiy Ivanov from Thercon, for their overall help and guidance.

Conflicts of Interest: The authors declare no conflict of interest.

\section{Nomenclature}

$\begin{array}{ll}\text { EV } & \text { Electric Vehicle } \\ \text { GHG } & \text { GreenHouse Gases } \\ \text { HFCH } & \text { Highway_Fast Charging_Highway } \\ \text { HP } & \text { Heat Pipe } \\ \text { LHP } & \text { Loop Heat Pipe } \\ \text { PCM } & \text { Phase Change Materials } \\ \text { TC } & \text { Thermocouple } \\ \text { TMS } & \text { Thermal Management System } \\ \text { SOC } & \text { State of Charge } \\ \Delta P_{\text {cap }} & \text { Capillary Pressure Gradient } \\ \bar{r} & \text { Pore Size Medium Radius } \\ \theta & \text { Meniscus Contact Angle } \\ \sigma & \text { Surface Tension }\end{array}$

\section{References}

1. Department for Business Energy \& Industrial Stratagy 2018 UK Greenhouse Gas Emissions. Available online: https:/ /www.gov. uk/government/statistics / final-uk-greenhouse-gas-emissions-national-statistics-1990-to-2018 (accessed on 15 November 2021).

2. Sandy Thomas, C.E. Transportation options in a carbon-constrained world: Hybrids, plug-in hybrids, biofuels, fuel cell electric vehicles, and battery electric vehicles. Int. J. Hydrogen Energy 2009, 34, 9279-9296. [CrossRef]

3. International Energy Agency (IEA). Global EV Outlook 2020; International Energy Agency (IEA): Paris, France, 2020.

4. International Energy Agency (IEA). Global EV Outlook 2021; International Energy Agency (IEA): Paris, France, 2021.

5. Noel, L.; de Rubens, G.Z.; Sovacool, B.K.; Kester, J. Fear and loathing of electric vehicles: The reactionary rhetoric of range anxiety. Energy Res. Soc. Sci. 2019, 48, 96-107. [CrossRef] 
6. Nagasubramanian, G. Electrical characteristics of 18650 Li-ion cells at low temperatures. J. Appl. Electrochem. 2001, 31, 99-104. [CrossRef]

7. Ramadass, P.; Haran, B.; White, R.; Popov, B.N. Capacity fade of Sony 18650 cells cycled at elevated temperatures. J. Power Sources 2003, 112, 614-620. [CrossRef]

8. Bandhauer, T.M.; Garimella, S.; Fuller, T.F. A Critical Review of Thermal Issues in Lithium-Ion Batteries. J. Electrochem. Soc. 2011, 158, R1. [CrossRef]

9. Lin, J.; Liu, X.; Li, S.; Zhang, C.; Yang, S. A review on recent progress, challenges and perspective of battery thermal management system. Int. J. Heat Mass Transf. 2021, 167, 120834. [CrossRef]

10. Qin, P.; Liao, M.; Zhang, D.; Liu, Y.; Sun, J.; Wang, Q. Experimental and numerical study on a novel hybrid battery thermal management system integrated forced-air convection and phase change material. Energy Convers. Manag. 2019, 195, 1371-1381. [CrossRef]

11. Tete, P.R.; Gupta, M.M.; Joshi, S.S. Developments in battery thermal management systems for electric vehicles: A technical review. J. Energy Storage 2021, 35, 102255. [CrossRef]

12. Wu, W.; Wang, S.; Wu, W.; Chen, K.; Hong, S.; Lai, Y. A critical review of battery thermal performance and liquid based battery thermal management. Energy Convers. Manag. 2019, 182, 262-281. [CrossRef]

13. Akinlabi, A.A.H.; Solyali, D. Configuration, design, and optimization of air-cooled battery thermal management system for electric vehicles: A review. Renew. Sustain. Energy Rev. 2020, 125, 109815. [CrossRef]

14. Ianniciello, L.; Biwolé, P.H.; Achard, P. Electric vehicles batteries thermal management systems employing phase change materials. J. Power Sources 2018, 378, 383-403. [CrossRef]

15. Smith, J.; Singh, R.; Hinterberger, M.; Mochizuki, M. Battery thermal management system for electric vehicle using heat pipes. Int. J. Therm. Sci. 2018, 134, 517-529. [CrossRef]

16. Van Gils, R.W.; Danilov, D.; Notten, P.H.L.; Speetjens, M.F.M.; Nijmeijer, H. Battery thermal management by boiling heat-transfer. Energy Convers. Manag. 2014, 79, 9-17. [CrossRef]

17. Bernagozzi, M.; Georgoulas, A.; Miché, N.; Rouaud, C.; Marengo, M. Novel battery thermal management system for electric vehicles with a loop heat pipe and graphite sheet inserts. Appl. Therm. Eng. 2021, 194, 117061. [CrossRef]

18. E, J.; Han, D.; Qiu, A.; Zhu, H.; Deng, Y.; Chen, J.; Zhao, X.; Zuo, W.; Wang, H.; Chen, J.; et al. Orthogonal experimental design of liquid-cooling structure on the cooling effect of a liquid-cooled battery thermal management system. Appl. Therm. Eng. 2018, 132, 508-520. [CrossRef]

19. De Vita, A.; Maheshwari, A.; Destro, M.; Santarelli, M.; Carello, M. Transient thermal analysis of a lithium-ion battery pack comparing different cooling solutions for automotive applications. Appl. Energy 2017, 206, 101-112. [CrossRef]

20. Xu, J.; Lan, C.; Qiao, Y.; Ma, Y. Prevent thermal runaway of lithium-ion batteries with minichannel cooling. Appl. Therm. Eng. 2017, 110, 883-890. [CrossRef]

21. Wang, Q.; Jiang, B.; Li, B.; Yan, Y. A critical review of thermal management models and solutions of lithium-ion batteries for the development of pure electric vehicles. Renew. Sustain. Energy Rev. 2016, 64, 106-128. [CrossRef]

22. Kim, J.; Oh, J.; Lee, H. Review on battery thermal management system for electric vehicles. Appl. Therm. Eng. 2019, 149, 192-212. [CrossRef]

23. Shen, M.; Gao, Q. Structure design and effect analysis on refrigerant cooling enhancement of battery thermal management system for electric vehicles. J. Energy Storage 2020, 32, 101940. [CrossRef]

24. Putra, N.; Ariantara, B.; Pamungkas, R.A. Experimental investigation on performance of lithium-ion battery thermal management system using flat plate loop heat pipe for electric vehicle application. Appl. Therm. Eng. 2016, 99, 784-789. [CrossRef]

25. Bernagozzi, M.; Charmer, S.; Georgoulas, A.; Malavasi, I.; Michè, N.; Marengo, M. Lumped parameter network simulation of a Loop Heat Pipe for energy management systems in full electric vehicles. Appl. Therm. Eng. 2018, 141, 617-629. [CrossRef]

26. Rao, Z.; Huo, Y.; Liu, X. Experimental study of an OHP-cooled thermal management system for electric vehicle power battery. Exp. Therm. Fluid Sci. 2014, 57, 20-26. [CrossRef]

27. Zhao, J.T.; Rao, Z.H.; Liu, C.Z.; Li, Y.M. Experiment study of oscillating heat pipe and phase change materials coupled for thermal energy storage and thermal management. Int. J. Heat Mass Transf. 2016, 99, 252-260. [CrossRef]

28. Liang, J.; Gan, Y.; Li, Y. Investigation on the thermal performance of a battery thermal management system using heat pipe under different ambient temperatures. Energy Convers. Manag. 2018, 155, 1-9. [CrossRef]

29. Maydanik, Y.; Chernysheva, M.; Vershinin, S. High-Capacity Loop Heat Pipe with Flat Evaporator for Efficient Cooling Systems J. Thermophys. Heat Transf. 2020, 34. [CrossRef]

30. Ren, Y.; Yu, Z.; Song, G. Thermal management of a Li-ion battery pack employing water evaporation. J. Power Sources 2017, 360, 166-171. [CrossRef]

31. Panchal, S.; Khasow, R.; Dincer, I.; Agelin-Chaab, M.; Fraser, R.; Fowler, M. Thermal design and simulation of mini-channel cold plate for water cooled large sized prismatic lithium-ion battery. Appl. Therm. Eng. 2017, 122, 80-90. [CrossRef]

32. Zhou, G.; Li, J.; Jia, Z. Power-saving exploration for high-end ultra-slim laptop computers with miniature loop heat pipe cooling module. Appl. Energy 2019, 239, 859-875. [CrossRef]

33. Maydanik, Y.F.; Chernysheva, M.A.; Pastukhov, V.G. Review: Loop heat pipes with flat evaporators. Appl. Therm. Eng. 2014, 67, 294-307. [CrossRef] 
34. Bai, L.; Fu, J.; Lin, G.; Zhou, C.; Wen, D. Quiet power-free cooling system enabled by loop heat pipe. Appl. Therm. Eng. 2019, 155, 14-23. [CrossRef]

35. Vlassov, V.V.; Riehl, R.R. Mathematical model of a loop heat pipe with cylindrical evaporator and integrated reservoir. Appl. Therm. Eng. 2008, 28, 942-954. [CrossRef]

36. Bandhauer, T.M.; Garimella, S. Passive, internal thermal management system for batteries using microscale liquid-vapor phase change. Appl. Therm. Eng. 2013, 61, 756-769. [CrossRef]

37. An, Z.; Jia, L.; Li, X.; Ding, Y. Experimental investigation on lithium-ion battery thermal management based on flow boiling in mini-channel. Appl. Therm. Eng. 2017, 117, 534-543. [CrossRef]

38. Zhang, T.; Gao, Q.; Wang, G.; Gu, Y.; Wang, Y.; Bao, W.; Zhang, D. Investigation on the promotion of temperature uniformity for the designed battery pack with liquid flow in cooling process. Appl. Therm. Eng. 2017, 116, 655-662. [CrossRef]

39. Chang, L.; Wang, J.; Wang, X.; Chen, Y.; Zhang, Z.; Feng, X. The solutions to electric vehicle air conditioning systems: A review. Renew. Sustain. Energy Rev. 2018, 91, 443-463. [CrossRef]

40. Tomaszewska, A.; Chu, Z.; Feng, X.; O’Kane, S.; Liu, X.; Chen, J.; Ji, C.; Endler, E.; Li, R.; Liu, L.; et al. Lithium-ion battery fast charging: A review. eTransportation 2019, 1, 100011. [CrossRef]

41. Sun, L.; Li, G.; You, F. Combined internal resistance and state-of-charge estimation of lithium-ion battery based on extended state observer. Renew. Sustain. Energy Rev. 2020, 131, 109994. [CrossRef]

42. $\mathrm{Ku}, \mathrm{J}$. Operating Characteristics of Loop Heat Pipes. In Proceedings of the 29th International Conference on Environmental System, Denver, CO, USA, 12-15 July 1999; p. 16. 